\title{
THE EFFECTS OF AGEING POPULATION ON THE ECONOMY AND ON SERVICE ACTIVITIES IN ROMANIA
}

\author{
Cecilia Irina RABONȚU, Amalia Venera TODORUȚ \\ "Constantin Brâncuși" University of Targu Jiu, Romania \\ cecilia.rabontu@gmail.com, , amalia_venera@yahoo.com
}

\begin{abstract}
Romania's ageing population is a fact well established by specialists in statistical data analysis. The effects of this irreversible phenomenon, which is difficult to counteract in the current circumstances, are multiple - on the economy, generally, but especially on the service activities which are necessary for the target population - "old age" - in order to increase their quality of life. In this paper we proposed to analyze the level of ageing of the Romanian population, to identify the effects of this phenomenon on the economy and on the major economic sectors with emphasis on service activities. Tertiary sector activities are divided into two categories namely: those that can improve the quality of life of elders and services absolutely necessary for them - elderly care services, medical services, spa treatment services, social services etc.In order to achieve the objectives proposed in this paper, we used the analysis of the specialized literature on this subject up to this point and the descriptive statistics with which we interpreted the statistical data found in the official databases. The results of this study are to establish the existing relationship between the ageing process of the Romanian population and the response of the economy, and especially of the services to the needs of the elderly.
\end{abstract}

Keywords: Population ageing; Quality of life; Effect on the economy; Service Activities; Romania

\section{Introduction}

The demographic ageing process has many consequences and implications. Thus, the change in the ratio between the active and the passive population leads to an increase in the population of addicts, on the account of non-productive adults, a phenomenon that creates difficult medical and socioeconomic problems. The most important consequences are the ageing process of the population on social protection and health care for the elderly, which is the largest population group as addressable, while being the population category in which age changes cause significant increases in mortality and disability, and where is found the transition from the infectious pathology specific to younger ages to the degenerative chronic pathology of older ages. (Negara A., 2013)

The most visible economic effects caused by population decline and ageing in Romania refers to the economic growth slowing down, maintaining Romania's dependence on foreign capital and increasing pressure on the state budget in the long term.

Nowadays, the experts say that one of seven Romanian has more than 65 years and because of the absence of birth rate improvements in 2030 one of five Romanian will be over 65 years, following that in 2060 the report will be one of third. 
According to some studies done by the European Commission, in the next decades, the proportion of older people will increase rapidly in all the EU countries, while the proportion of the working age population will decrease significantly. Although, life expectancy is a major achievement, ageing is a major challenge for the economy and for European systems of social protection. The demographic transition is considered one of the most important challenges facing the EU. The population of Europe where Romania also fits, lives more than ever before, aspect doubled by the sharp decline of the number of children. These two issues inevitably lead to increasing the proportion of retirees but also to decreasing the proportion of people of working age. In the European Union it is expected that by 2060 there will be only two workers for every person aged 65 or more.

According to The 2015 Ageing Report, the demographic changes that will occur in the future concern:

- The EU's population will increase by $3 \%$, from 507 million people in 2013 to 523 million individuals in 2060;

- The average life span will also increase, meaning that we will live longer, namely men will live up to 84 years in 2060 compared to 77.6 years in 2014 and women will live up to 89.1 years in 2060 compared to 83.1 years in 2013. The European countries population currently suffers a second major trend: the emergence of a new group - the "fourth age" ("the eldest of the elders", over 80 years persons) with high share and in a continuous growth.

- The active population will decrease by $4.4 \%$ from 211 million workers in 2013 to 202 million workers in 2060 .

- There will be more active older people then younger people, meaning that people between 0-14 years will have the same percentage in 2060 compared to 2013, namely $15 \%$, the percentage of people between $15-64$ will drop by $10 \%$ (66\% in 2013 and $56.6 \%$ in 2060), those between $65-79$ years will grow by $3 \%$ in 2016 and will represent $16.6 \%$, and the percentage of people over 80 years will increase by $6.7 \%$ in 2060 . We have witnessed the decline in the share of young people, aged $0-14$, from $23.7 \%$ (in 1990) to $15.0 \%$ (in 2012) and the growth of the elderly, 65 years and older, from $10.3 \%$ (in 1990 ) to $15.0 \%$ (in 2012). The adult population, aged 15-64, has grown steadily from $66 \%$ (in 1990) to $70 \%$ (in 2012);

- If in 2013 four workers supported one pensioner, in 2060 just two workers will have to support one pensioner.

All this will lead to health spendings increasing from $6.8 \%$ in 2013 to $7.8 \%$ in 2060, long-term care of the elderly spendings increasing from $1.6 \%$ in 2013 to $2.7 \%$ in 2016 , social security and pensions spendings and other effects on economy and services offered to age groups analyzed.

Thus, statistics show that in 2080 Romania will have a total population of about 16.3 million people and the ratio between the old and the young population will increase from $24 \%$ in 2013 to $50 \%$ in 2080 . (Cretu, 2015)

Population ageing is a global phenomenon, directly linked to the everyday aspects of human life, and addresses the issues on which economic prosperity depends: investment and spending, the labor market, pensions, taxation and the transfer of property to another generation. This process also has consequences on the structure of morbidity and mortality of the population, composition of families, living conditions. The number of elderly people grows globally by $2 \%$ per year, much faster than the natural increase of the population. (Negara and others, 2013)

\section{The method of research}

In this paper, in order to respond to the proposed goal, we have followed the fundamental and theoretical research to identify the opinions of other authors who have been concerned about this topic, but also the evaluation research that will support us in establishing the state of facts regarding the objectives of the paper using statistical data. Thus, after studying the topic, we studied the specialized bibliography, extracted from it the most 
relevant aspects of population ageing, its influences on the economy, its services and its role in responding to the needs of the elderly. In the study of the bibliography, we approached the results orientation in the sense that we presented and analyzed the existing results in relation to the subject treated or related issues.

To conduct the study, we also followed the collection of the necessary statistical data from official statistics at national and international level and we proceeded to analyze them. Both qualitative data analysis and quantitative analysis were used.

\section{The population ageing in Romania in statistics}

Romania's population aligns European Union evolution in terms of ageing, being foreseeable the effects that ageing has on the conduct of economic and social life and also on the prospects of demographic trends, issues highlighted also by the reports of dependence. In early 2012, there were 430 young and older people (elderly people representing 50\%) for 1,000 adults, compared to 505 young and elderly in 1992 (when the share of the elderly population was $30 \%$ ). In 2015, 433 young people and elderly (elderly people representing 51\%), situation achieved primarily due to the decrease of the young population (0-14 years). The number of elderly, 65 years and over, per 1000 adults increased from 156 (in 1990), to 165 (in 1992), 215 (in 2012) and 222 (2015), generating, in time, an increased social task for adults. Detailed aspects of population evolution in Romania is shown in Table 1.

Table No. 1. Romania's population, by age, on 1st July

\begin{tabular}{|c|c|c|c|c|c|c|c|c|c|}
\hline \multirow{3}{*}{$\begin{array}{l}\text { Ages } \\
\text { and } \\
\text { age } \\
\text { groups }\end{array}$} & \multicolumn{7}{|l|}{ Ani } & \multirow[b]{2}{*}{2016} & \multirow[b]{2}{*}{2017} \\
\hline & 1992 & 2000 & 2005 & 2010 & 2013 & 2014 & 2015 & & \\
\hline & \multicolumn{7}{|c|}{ UM: number of people } & & \\
\hline Total & 23126797 & 22809610 & 22621457 & 22492083 & 22359849 & 22299730 & 22260158 & 22236059 & $\underline{22201702}$ \\
\hline $0-4$ & 1629684 & 1168313 & 1130199 & 1151145 & 1085133 & 1044168 & 1018494 & 1024139 & 1019287 \\
\hline 5-9 & 1705984 & 1261613 & 1161543 & 1127823 & 1139424 & 1145756 & 1149525 & 1136602 & $\underline{1121508}$ \\
\hline $10-14$ & 1887927 & 1789483 & 1258440 & 1158990 & 1139003 & 1128849 & 1125102 & 1126650 & 1134649 \\
\hline $15-19$ & 1909028 & 1693991 & 1783930 & 1255343 & 1165882 & 1150170 & 1153291 & 1151740 & $\underline{1147645}$ \\
\hline $20-24$ & 2145998 & 1939673 & 1687989 & 1777993 & 1479470 & 1372592 & 1253073 & 1218581 & $\overline{1178388}$ \\
\hline $25-29$ & 1317562 & 1835560 & 1928686 & 1680667 & 1738130 & 1775190 & 1779388 & 1712124 & 1605357 \\
\hline $30-34$ & 1550481 & 1902799 & 1819518 & 1915147 & 1774564 & 1706012 & 1681005 & 1649024 & $\overline{1686387}$ \\
\hline $35-39$ & 1754492 & 1322989 & 1881786 & 1803481 & 1895289 & 1917056 & 1907306 & 1892611 & 1847367 \\
\hline $40-44$ & 1578437 & 1636742 & 1302691 & 1858495 & 1858757 & 1794157 & 1789462 & 1806002 & 1841787 \\
\hline $45-49$ & 1193663 & 1623054 & 1596738 & 1276919 & 1522743 & 1692659 & 1832748 & 1950590 & 2023570 \\
\hline $50-54$ & 1315351 & 1336308 & 1563878 & 1544723 & 1343459 & 1286302 & 1244822 & 1203374 & $\overline{1214934}$ \\
\hline $55-59$ & 1351557 & 1067959 & 1267859 & 1489225 & 1541886 & 1541234 & 1479784 & 1425402 & 1362203 \\
\hline $60-64$ & 1240708 & 1236016 & 987915 & 1183573 & 1366323 & 1364544 & 1396813 & 1422064 & 1442177 \\
\hline $65-69$ & 1041560 & 1093233 & 1101636 & 892259 & 930626 & 995016 & 1079767 & 1144667 & 1193000 \\
\hline $70-74$ & 600692 & 890432 & 919544 & 944875 & 840466 & 813892 & 777121 & 784020 & 793459 \\
\hline $75-79$ & 451728 & 603683 & 677665 & 720682 & 743960 & 752796 & 758175 & 728844 & $\overline{708048}$ \\
\hline $80-84$ & 310265 & 222178 & 386857 & 454402 & 487022 & 494063 & 498295 & 506960 & $\underline{513513}$ \\
\hline $\begin{array}{l}85 \text { and } \\
\text { over }\end{array}$ & 141680 & 185584 & 164583 & 256341 & 307712 & 325274 & 335987 & 352665 & $\underline{368423}$ \\
\hline
\end{tabular}

Source: http:titistatistici.insse.rotishoptiindex.jsp? page $=$ tempo3\&lang $=$ ro\&ind $=$ POP108D

In the context of Romania's population, it decreases from year to year by percentages between $0.3 \%$ and $1.03 \%$ it is found that the number of people over 65 years increases. What is interesting is that in recent years in Romania exists a tendency of higher growth in the number of elderly people "85 and over" (from 141700 in
1992 to 335987 in 2015 and 368423 in 2017), detail noticed also to the group of elderly "younger". This development may have impacts on the economy as a whole but also on service activities dedicated to this age group or requested by them. The evolution of these population groups can be seen in the figure below: 


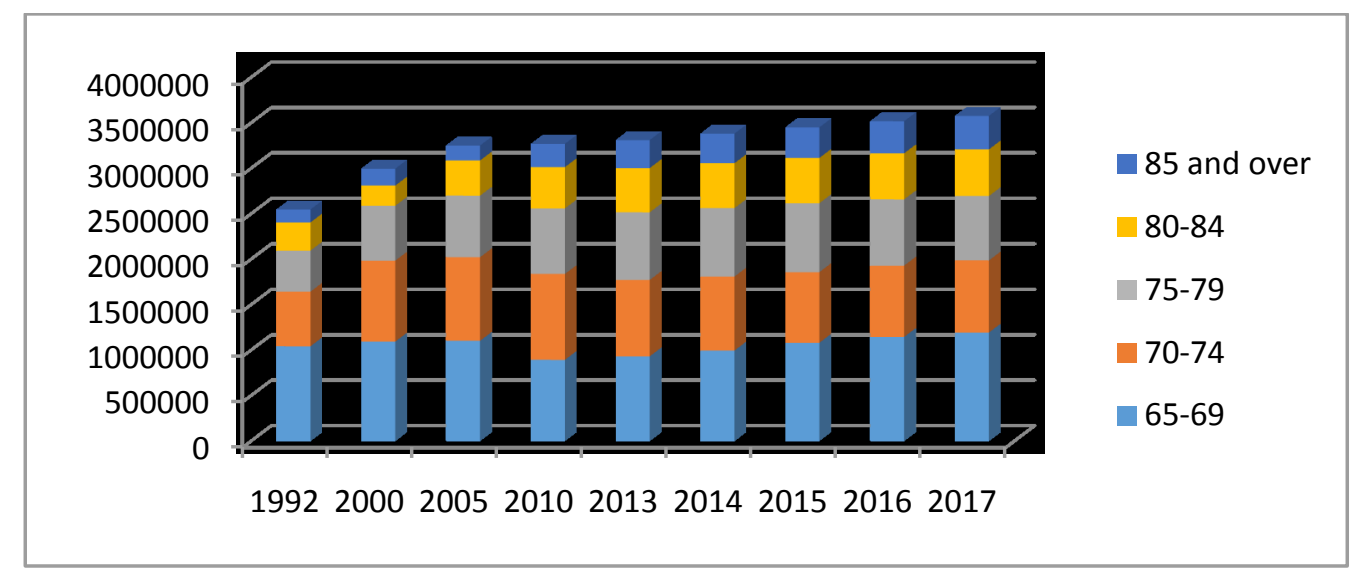

Figure 1. Evolution of Romania population aged 65 and over by age group in the period $1992-2017$

According to BCR [1] report about population ageing we will witness in the future interesting but also worrying evolutions in terms of social security budget in the sense that it predicts that "in 2030 women will live to pension for 22 years and men for 17; gradually increasing the standard of living during their working life will influence retired people to be less willing to accept a change in the standard of living after 65 years due to the income decline; public pension must be completed with other financial resources that must be acquired from the age of 30 years".

For a relevant picture of population evolution by age group, over a considerable period of time, we present the age pyramid in Romania in 1977, 2002 and 2017.

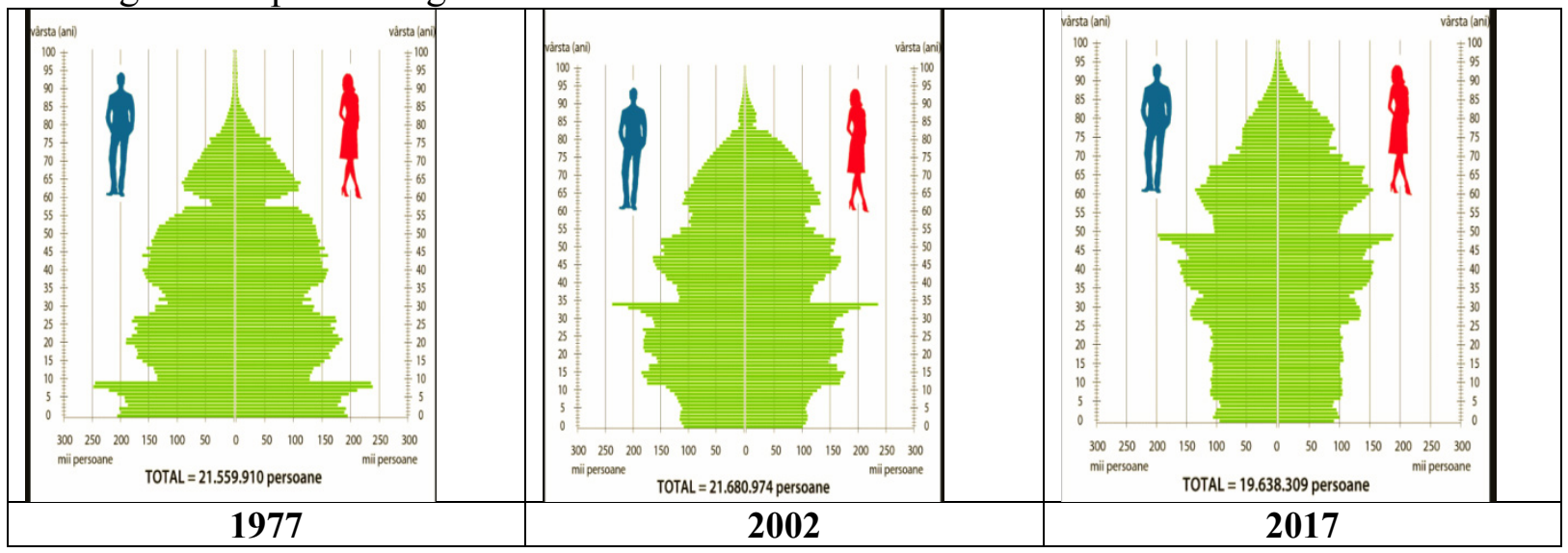

Figure 2. The Pyramid of Ages in Romania

Source: www.insse.ro, http://www.insse.ro/cms/files/despre/Piramida_Ro_1956-2017.gif

It can be noticed what is the pressure of older people on those who are still active. It is worrying to see the reduction of the young population and implicitly the decreasing of the birth rate. These developments also entail relevant economic and social pressures on national budgets and on some sectors of activity providing services to the elderly.

However, if we take into consideration also the life expectancy at birth increasing to 75 years in 2011 from 70 years in 1990 and to
77 years in 2015, we must realize strengthening the share of the population over 65 years in total population. In 2011 for every person over 65 there were 5 people of working age (15-64 years), but less of a person who was paying employee contributions to the public pension system. In 2015 this ratio decreased to 4.5 people of working age for an elderly person.

We consider it necessary to also present the elderly poverty rate compared to other age groups as a first step in determining 
the quality of life of this category of people. According to the National Institute of Statistics of Romania, the relative poverty rate is defined as the percentage of poor people (using the relative estimation) in total population. It is considered poor people the persons in households with a disposable income per adult - equivalent (including or excluding value of consumption from own resources) below the poverty threshold.

Table No. 2. The relative poverty rate, by age group, in Romania during 2007-2016

\begin{tabular}{|c|c|c|c|c|c|c|c|c|c|c|}
\hline \multirow{3}{*}{$\begin{array}{l}\text { Age } \\
\text { groups }\end{array}$} & \multicolumn{10}{|c|}{ Years } \\
\hline & 2007 & 2008 & 2009 & 2010 & 2011 & 2012 & 2013 & 2014 & 2015 & 2016 \\
\hline & \multicolumn{10}{|c|}{ UM: Percentage } \\
\hline $\begin{array}{l}\text { Total } \\
\text { people }\end{array}$ & 24,8 & 23,4 & 22,4 & 21,1 & 22,2 & 22,6 & 22,4 & 25,4 & 25,4 & 25,3 \\
\hline $0-17$ years & 32,8 & 32,9 & 32,9 & 31,3 & 32,9 & 34,6 & 32,1 & 39,4 & 38,1 & 37,2 \\
\hline $\begin{array}{l}18-64 \\
\text { years }\end{array}$ & 21,1 & 20 & 19,8 & 19,2 & 21 & 21 & 21,5 & 23,8 & 23,3 & 23,3 \\
\hline $\begin{array}{l}65 \text { years } \\
\text { and over }\end{array}$ & 30,6 & 26 & 21 & 16,7 & 14,1 & 15,4 & 15 & 15,5 & 19,4 & 19,1 \\
\hline
\end{tabular}

Source: (C) 1998 - 2016 National Institute of Statistics

It is interesting to note that people in the age group ,65 and over" shows a poverty rate plummeted in the sense that if in 2007 was $30.6 \%$ in 2014 only $15.5 \%$ were in the category of people who had disposable income per adult - equivalent below the poverty threshold. It should be noted that the situation presented in Table No.2 refers to the population affected by poverty $(25 \%$ in 2016) of which $19.1 \%$ is the age group „65 and over".

It is well known that providing financial resources for older people is done through four main ways:

1. the public pension system,

2. the private pension systems

3 . the transfer of resources from the younger members of the family to the elderly

4. the use of financial and non-financial assets accumulated during their working lives.

All these methods meet constraints in the case of Romania. In 2016, 25,3\% of Romania's total population was affected by severe material poverty. The vulnerability of the elderly facing severe material poverty is slightly higher than that of people aged under 65 years. The main response of the authorities must be the economic development that can reduce poverty areas (agriculture-oriented market) and only secondarily social aid providing.
4. The effects of ageing on the economy and on service activities

In terms of longevity, each of us aspiring to live long and in good health, but society must provide an enabling environment for older people continuing to ensure intergenerational equity in all areas of social life [2]. The ageing trend of the population has a profound impact on generations and on most of the areas of economic and social activity: labor market, social protection, education, culture, politics [3].

It is highlighted in specialized studies that demographic developments will make the concerns of EU member states, included Romania, to turn to numerous problems among which we mention the following: the cost of pensions strategies in education and training, housing, transport, healthcare, infrastructure specific public, tax reforms, structural reforms, public expenditure.

The European Union Council considers it necessary to continue EU reforms in all fields that are age related especially those related to spending on pensions, health, long-term care with specificity for each country without eliminating the strengthening sustainability context. It is requested to be taken into consideration the economic and budgetary consequences of ageing and to try to reduce public debt, raising employment rates and productivity 
and reforming pension, health care and long-term care systems. The problem arises even raising the retirement age to avoid early exit from the labor market and by linking retirement age to life expectancy or pension.

The effects of ageing on the economy[4] can be found in:

1. the potential GDP decline, respectively the decreasing of the capital role, demography and productivity, issues found in the diminishing contribution of labor and capital in terms of domestic savings damage. Although Romania has a good macroeconomic situation, the issue is on potential GDP growth, which is much lower than in the period 20052008 , when it was at almost $5 \%$ per year and overcame the economy, while in recent years was located about $2 \%$ $2.5 \%$. Given the contraction in private investment, the ageing process and reducing process of the number of inhabitants overlapping structural problems in the labor market in Romania and an excessive agriculture and yet reduced in services, it is necessary to find solutions in downward percentage population employed in agriculture (29\% in Romania compared with $3.4 \%$ in the Eurozone) and increase employment in the service sector $(42 \%$ of the labor force employed in Romania, compared to $72 \%$ in the Eurozone). It can be also accepted the idea of leaving on the workforce those able to the age of 65 and older, the implementation of a program for the return of Romanians abroad, to boost the birth rate through better allotments, to increase the flexibility of labor work and of judicious distribution territorially and on activity fields etc.

2. The exerting of an increasing pressure on the state budget both in terms of revenue and expenditure. On revenue should be specified affecting economic growth by increasing the number of inactive people to be supported by a small number of workers but also in terms of budgetary revenues in GDP, being $32.9 \%$ in 2014 and $31,9 \%$ in 2017, one of the lowest in the European Union[5]; and on the expenditure side, it must be aware of spending increasing for social assistance and health.

3. Internal rate of saving and investment damage, aspect reflected in the fact that individuals tend to consume constantly during their lifetime unlike income trends that are maximum during the maturity of individuals that coincide with working life and lower in childhood and to elderness. In order to reduce the Romania's dependency from external capital and domestic financing of economic growth it must be encouraged population saving in all possible forms, namely deposits, private pension funds, investment funds, capital market, life insurance and bonds .

The effects of ageing on service activities are found larger in the case of health care services, long term care, spa treatment, tourism services for elderly, religious services, social and social security services, etc.

In order to identify those services consumed by retirees, i.e. the age group of 65 years and older, we present total consumption expenditures monthly average per household:

Table No. 3. Total consumption expenditure monthly average per household, by category of expenditure for pensioners, in period 2005-2017 - lei

\begin{tabular}{|c|c|c|c|c|c|c|c|c|c|c|c|c|c|}
\hline $\begin{array}{l}\text { Expenditure } \\
\text { categories }\end{array}$ & 2005 & 2006 & 2007 & 2008 & 2009 & 2010 & 2011 & 2012 & 2013 & 2014 & 2015 & 2016 & $\begin{array}{l}\text { Trim } \\
\text { II } \\
2017\end{array}$ \\
\hline $\begin{array}{l}\text { Total consumption } \\
\text { expenditure }\end{array}$ & 695 & 777 & 880 & 1135 & 1253 & 1286 & 1330 & 1393 & 1427 & 1362 & 1396 & 1456 & 1554 \\
\hline $\begin{array}{l}\text { Food products and } \\
\text { non-alcoholic } \\
\text { beverages }\end{array}$ & 331,9 & 351,3 & 398,5 & 490,4 & 534,3 & 544,7 & 575,6 & 608,7 & 615,3 & 574,5 & 563,1 & 560,7 & 604,3 \\
\hline $\begin{array}{l}\text { Alcoholic beverages, } \\
\text { tobacco }\end{array}$ & 37,7 & 43,2 & 53,6 & 66,3 & 79,9 & 84,8 & 88,3 & 95 & 99,5 & 89,7 & 93,4 & 97,7 & 111,6 \\
\hline Clothing and shoes & 32,1 & 35,9 & 45,5 & 59 & 61,1 & 55,1 & 50,8 & 53,7 & 57,9 & 53,9 & 58 & 70,9 & 81,9 \\
\hline $\begin{array}{l}\text { Housing, water, } \\
\text { electricity, gas and } \\
\text { other fuels }\end{array}$ & 117,6 & 135,4 & 150,5 & 198,2 & 220,9 & 236,6 & 237,5 & 251,05 & 259,6 & 255,4 & 276,9 & 284,06 & 261,2 \\
\hline
\end{tabular}




\begin{tabular}{|c|c|c|c|c|c|c|c|c|c|c|c|c|c|}
\hline $\begin{array}{l}\text { Furniture, equipment } \\
\text { and maintenance of } \\
\text { the dwelling }\end{array}$ & 23,4 & 26,7 & 34,9 & 50,4 & 56,6 & 54,4 & 56 & 55,1 & 57,4 & 58,6 & 65,2 & 75,8 & 102,2 \\
\hline Health & 46,07 & 58,98 & 61,15 & 82,56 & 98,29 & 102,25 & 105,83 & 107,24 & 109,64 & 110,98 & 114,95 & 118,41 & 130,36 \\
\hline Transport & 32,64 & 40,69 & 34,67 & 50,85 & 49,91 & 58,04 & 57,24 & 63,72 & 59,72 & 55,14 & 57,55 & 62,37 & 66,24 \\
\hline Communications & 27,86 & 31,46 & 36,84 & 45,94 & 53,61 & 53,93 & 53,84 & 57,04 & 59,11 & 55,88 & 61,51 & 67,1 & 70,33 \\
\hline Leisure and culture & 23,31 & 28,14 & 33,26 & 41,9 & 46,29 & 42,94 & 46,54 & 44,28 & 51,84 & 49,12 & 44,75 & 49,03 & 45,74 \\
\hline Education & 3,02 & 3,09 & 3,84 & 5,18 & 6,91 & 4,03 & 5,75 & 3,22 & 2,41 & 3,05 & 2,74 & 2,65 & 2,54 \\
\hline $\begin{array}{l}\text { Hotels, cafes and } \\
\text { restaurants }\end{array}$ & 4,15 & 4,92 & 5,7 & 12,05 & 10,36 & 10,12 & 9,37 & 9,31 & 9,2 & 10,93 & 10,22 & 11,01 & 12,27 \\
\hline $\begin{array}{l}\text { Various products and } \\
\text { services }\end{array}$ & 15,91 & 17,77 & 22,36 & 32,51 & 34,94 & 39,33 & 43,67 & 44,61 & 45,44 & 44,73 & 48,61 & 56,17 & 65,19 \\
\hline
\end{tabular}

Source: http://statistici.insse.ro/shop/

In the analyzed period it can be noted that in the 2015 the pensioners expenses amounted to 1362 lei, same amount as in 2014 but lower by $4.7 \%$ compared to 2013 and increased by $95 \%$ compared to the first year of analysis, more precisely - 2005 .

In 2017, the situation is better, with an increase of the total rents to 1554 lei, which is distributed to the categories of services presented with significant increases in food, health, communications, recreation and hotels, restaurants.

It is interesting, however, to see the share of expenditure on services.
In 2005 the most of the expenses incurred by retirees are found in food and nonalcoholic beverages, namely $47 \%$ and $11.38 \%$ for alcoholic beverages and tobacco. As regarding service activities for elderly $16.91 \%$ of expenditure can be found in housing, water distribution, electricity, gas, $6.62 \%$ in health services, $4.69 \%$ in transport services, $4 \%$ for communications services, and $3.35 \%$ for recreation and culture. Shares below 1\% are found in education and hotels, bars and restaurants spending.

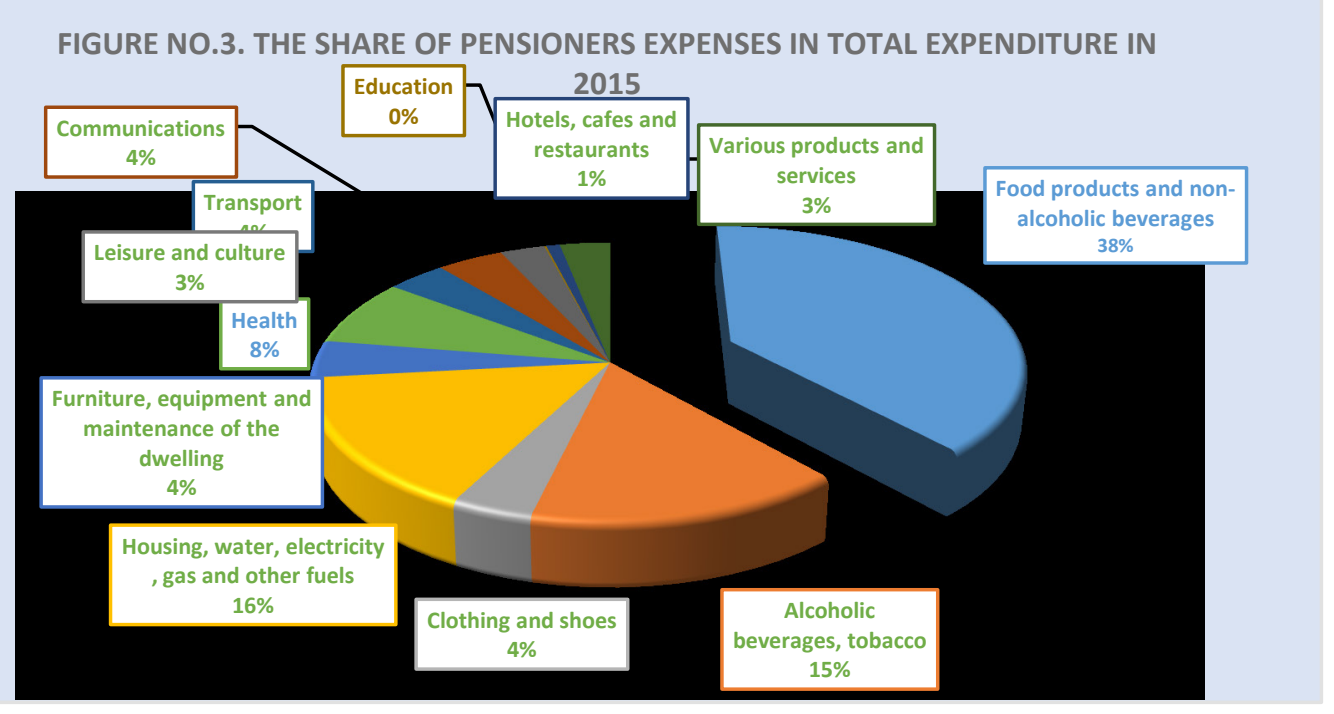

It is noted that in 2015 the percentage of expenditure affected food and nonalcoholic beverages decreased by $5 \%$ compared to 2005, increasing spending on alcoholic beverages and tobacco to $16.65 \%$. As regarding special services for pensioners, the expenditures shows that $8.44 \%$ of total expenditure is affected to health services, $4.55 \%$ to communications services, less compared to 2005 for recreation and culture, education services, but more than $2 \%$ in 2015 for various products and services.
It is estimated that the population ageing will constrain health and social services to adapt to changing patterns of illness (rise of chronic diseases) and the types of patients. A particular importance will be given to target older people to live their old age in an active, healthy and independent manner. The challenge is favoring strategies focused on prevention, including improving quality and food, physical activity and intellectual way of life from young and middle-aged people[6]. 
The very old people need health and care services more numerous and essentially different from those needed by the younger population. The morbidity of the very old people is characterized by a higher rate (more often tend to be sick), chronicity, multimorbidity. A typical old age is dementia disorder that requires professional care[7].
A category of special services for elderlycare services - can be offered in individual system at home or in a centralized manner through authorized institutions to provide these services. It can be analyzed through statistical data taking into discussion the elderly homes:

Table No.4. Homes for the elderly - end of year

\begin{tabular}{|l|l|l|l|l|l|l|l|l|l|l|}
\hline $\begin{array}{l}\text { Public homes - number of } \\
\text { units }\end{array}$ & 81 & 98 & 88 & 95 & 108 & 103 & 105 & 118 & 123 \\
\hline $\begin{array}{l}\text { Private homes - number of } \\
\text { units }\end{array}$ & 42 & 51 & 63 & 80 & 95 & 126 & 141 & 194 & 246 \\
\hline \begin{tabular}{l} 
Total \\
\hline
\end{tabular} & 123 & 149 & 152 & 175 & 203 & 229 & 246 & 322 & 369 \\
\hline
\end{tabular}

Source: http://statistici.insse.ro/shop/index.jsp? page $=$ tempo3\&lang $=$ ro\&ind $=A S S 113 B$

Made to meet the need for elderly care services, and not only, homes have had an upward trend over the period under review, both in terms of the number of public and private homes. Private homes, which number was under the public ones, in 2008-2012, outpaced the public sector in 2013, reaching to double in 2016.

The payment for community services provided for elderly persons in homes is as follows:

1. elderly people who have their own income must pay a monthly maintenance contribution, established on the basis of average monthly cost of maintenance;

2 . the monthly contribution is determined by the management of the Home, depending on the degree of dependence of the elderly cared for, of its revenues or of thelegal tutors revenues;

3. the obligation pay monthly maintenance contribution is established by a payment commitment, signed by the person with disabilities to be cared for in the home, or if it is devoid of capacity, by his legal representative.
The social services for protection of the elderly can be classified into: residential services, temporary or permanent care at home.

The community services in homes can be classified as:

a) social services: household aid; legal advice and administrative matters; ways to prevent social exclusion and social reintegration.

b) social and medical services: help with rehabilitation of physical and intellectual capacities; assistance for personal hygiene; providing occupational therapy programs.

c) medical services: consultations and treatments; care / nursing; the provision of drugs; providing medical devices

As regarding services related to spa sector regarded as services provided especially to the elderly we can say that Romanians have a culture spa, which is accessed as an acquired right for pensioners and members of trade unions, using tickets matched as part of a social policy that it raises the question of how long would it last. 
Table No.5. Tickets for treatment and rest granted by social insurance

\begin{tabular}{|c|c|c|c|c|c|c|c|c|c|c|c|}
\hline & U.M & 2007 & 2008 & 2009 & 2010 & 2011 & 2012 & 2013 & 2014 & 2015 & 2016 \\
\hline $\begin{array}{l}\text { Statersocial } \\
\text { insurance, where: }\end{array}$ & thousands & 313,8 & 325,4 & 286,4 & 169.8 & 228,5 & 202,1 & 189 & 210 & 207 & 212 \\
\hline Spa treatment & thousands & 261,8 & 250,8 & 214,9 & 169,8 & 198,8 & 202,1 & 189 & 210 & 207 & 212 \\
\hline Rest & thousands & 53 & 74,6 & 71,5 & - & 29,7 & - & - & $:$ & & $:$ \\
\hline $\begin{array}{l}\text { Expenses } \\
\text { incurred } \\
\text { treatment } \\
\text { rest }\end{array}$ & $\begin{array}{l}\text { Millions } \\
\text { LEI }\end{array}$ & 314,7 & 315,9 & 345,5 & 239,8 & 303,6 & 296,7 & 291,1 & 288,5 & 283,5 & 288,4 \\
\hline
\end{tabular}

The data presented in Table No.5 shows that every year the appropriations for the payment of tickets fot spa treatment are decreasing while those for recreation disappear, issues that negatively affect the quality of life of the elderly, fact that reduce their ability to use such tourism especially the lack of resources that may be affected for rest and treatment.

If in Western Europe, people over 75 years generally have a relatively modest standard of living than the average population, and overall, the average life of seniors is slightly above the average total population in western-european countries, those over 75 years have in this case a standard of living higher than those under 55 years. In this context, it is increasingly more often noted some strategies for a beautiful population ageing in the prevention of complications of chronic diseases (hypertension, sensory disturbances of gait, of the balance); favorable health behaviors (physical activity and sports, healthy nutrition); individually and collectively to improve the environment and quality of life of elderly: housing, technical aids, city planning; strengthening the social role of seniors, etc.

\section{Conclusions}

At the end of this paper are required some eloquent conclusions, namely: Romania's population faces an unprecedented ageing phenomenon in the context of the declining population and especially a declining in employment. Also, increasing the life span contributes to increased pressure on the state budget in the case that social security and health expenses for the elderly are increasing. This development has major implications for the economy in terms of gross domestic product decrease potential damage to domestic savings rate and default investment but also on the budget.

The services that are specific to this age group are becoming more numerous in terms of ensuring a decent standard of living but also to beautifully aging and increasing the quality of life. We have to consider the services offered by elderly homes, the health ones, sports services, rest and treatment, social services and others, which are actually the activities that can contribute substantially to improving the living conditions of the elderly towards achieving the level of Western countries. Thus, it is requires a comprehensive political approach, encompassing aspects related to the economy, employment, social issues. Romanian society must guarantee not only providing an adequate environment for older people, but also the economic and social viability in an aging world.

\section{References}

[1] BCR Research, 2013, Economic implications of population ageing in Romania

[2] Les tendances en matière de population en Europe et leur sensibilité aux mésures des pouvoirs publics, Asamblée parlamentaire, mai 2004

[3] Ana Bălaşa - Îmbătrânirea populației: provocări şi răspunsuri ale Europei, calitatea vieții, XVI, nr. 3-4, 2005, p. 273-288

[4] www.bcr.ro - BCR study: Economic implications of population ageing in Romania

[5] http://discutii.mfinante.ro/static/10/Mfp/buget2014/RAPORTBUGET 2014.pdf accesed iun 2015 and Raport buget 2017 accesed ian 2018 
[6] Soins de santé et soins pour les personnes agées: soutenir les strategies nationales visant un degré elèvé de protection sociale, Commission des Communautés europeènnes, 03.01.2003.

[7] Ana Bălaşa- Îmbătrânirea Populaţiei: Provocări si Răspunsuri ale Europei, CALITATEA VIEŢII, XVI, nr. 3-4, 2005, p.280 